\title{
Pyrosequencing analysis of eukaryotic and bacterial communities in faucet biofilms
}

\author{
Ruyin Liu ${ }^{\text {a }}$, Zhisheng Yu ${ }^{\mathrm{a}, *}$, Hongguang Guo ${ }^{\mathrm{a}}$, Miaomiao Liu ${ }^{\mathrm{b}}$, Hongxun Zhang ${ }^{\mathrm{a}}$, Min Yang ${ }^{\mathrm{b}}$ \\ a College of Environmental and Resource Sciences, Graduate University of Chinese Academy of Sciences, 100049, Beijing, China \\ b Research Center for Eco-Environmental Sciences, Chinese Academy of Sciences, Beijing, 100085, China
}

\section{H I G H L I G H T S}

- The about 2 year-old biofilm showed the characteristics of a young biofilm community.

- Hartmannella, a dominant eukaryotic predator, correlated closely with biofilm bacterial biomass.

- No obvious association of potential pathogens with amoebae in the faucet biofilms.

- Legionella is more sensitive to residual chlorine than Mycobacterium.

\section{A R T I C L E I N F O}

\section{Article history:}

Received 4 June 2012

Received in revised form 4 July 2012

Accepted 8 July 2012

Available online 28 July 2012

\section{Keywords:}

Pyrosequencing

16S rRNA gene sequencing

Faucet biofilm

Bacterial community

Eukaryotic community

Pathogens

\begin{abstract}
A B S T R A C T
In order to understand the microbial communities in drinking water biofilms, both eukaryotic and bacterial communities in three faucet biofilms were characterized by 454 pyrosequencing and quantitative PCR approaches. Microbial assemblages of the biofilms were dominated by bacteria, with Sphingomonadales, Rhizobiales, and Burkholderiales comprising the major bacterial populations. Although about 2 years of biofilm development occurred, the microbial community at site WSW still demonstrates the characteristics of a young biofilm community, e.g. low biomass, abundant aggregating bacteria (Blastomonas spp. and Acidovorax spp.) etc. Hartmannella of amoebae was the dominant eukaryotic predator in the biofilms, and correlated closely with biofilm bacterial biomass. Nonetheless, there was no obvious association of pathogens with amoebae in the faucet biofilms. In contrast, residual chlorine seems to be a dominant factor impacting the abundance of Legionella and Mycobacterium, two primary potential opportunistic pathogens detected in all faucet biofilms.
\end{abstract}

(c) 2012 Elsevier B.V. All rights reserved.

\section{Introduction}

Biofilms are generally recognized as the primary source of microorganisms in drinking water distribution systems (DWDSs), and can lead to various health issues, such as protecting and supporting pathogenic microorganisms (Buswell et al., 1998), bacterial regrowth (LeChevallier et al., 1991), and depletion of disinfection agents (Regan et al., 2002). In order to understand microbial ecology in DWDS biofilms, cultivation-based and independent molecular approaches have been used to reveal biofilm communities from different locations or pipe materials (e.g. stainless steel, galvanized iron, polyvinyl chloride, etc.) within DWDSs (Feazel et al., 2009; Lee et al., 2007). Microbial growth and the presence of potential opportunistic pathogens have been detected in various endpoints of DWDSs, e.g. tap, showerheads, etc. (Feazel et al., 2009; Kormas et al., 2010). Many studies attribute the survival of opportunistic pathogens in DWDSs to resistance mechanisms such as complex cell wall, biofilm formation, and pathogenprotozoon interactions (Berry et al., 2006; Vaerewijck et al., 2005).

\footnotetext{
* Corresponding author at: Graduate University of Chinese Academy of Sciences, No. 19A Yuquanlu, Beijing 100049, China. Tel./fax: + 861088256462.

E-mail address: yuzs@gucas.ac.cn (Z.Yu).
}

The type of bacterial communities present in a DWDS and the disinfection regime applied can also affect pathogen survival and disinfection efficacy (Batte et al., 2003; Eichler et al., 2006). DWDS bacterial community can be influenced by chlorine levels, concentration of organic compounds, water temperature, and physicochemical characteristics of pipe materials (Niquette et al., 2001). In addition, the occurrence of bacterial community succession was observed in a model DWDS (Martiny et al., 2003), demonstrating a long-term development of biofilm formation in DWDSs.

While current understanding of the microbial ecology of DWDS has recently improved, one common shortcoming of many used molecular methods such as 16S rRNA gene library construction by cloning (Li et al., 2010) and gene fingerprinting arrays (Eichler et al., 2006), is the limited throughput, which may lead to masking and underestimating the real diversity of a microbial community (Liu et al., 2012). In contrast, pyrosequencing, a next generation sequencing technology which allows high-throughput sequencing has revolutionized the study of microbial diversity. The 454 pyrosequencing platforms can provide about 400 bp reads, which allows a reliable annotation of the DNA fragments. This method has been widely applied to study microbial diversity in soils (Jones et al., 2009), freshwater (Roh et al., 2010), wastewater treatment facilities (Ye and Zhang, 2011), 
and human guts (Nam et al., 2011). Recently, a preliminary study based on 454 pyrosequencing successfully characterized bacterial biofilm communities from two water meters in the genus level (Hong et al., 2010), indicating the feasibility of this approach in revealing microbial diversity in DWDSs.

Eukaryotic protozoa are reported to be closely associated with environmental bacterial biofilms (Hunt and Parry, 1998). The effects of protozoan grazing on the biofilm community are probably the most important factor controlling biofilm bacterial communities (Pedersen, 1990). In addition, protozoa, especially amoebae, may facilitate some human-pathogenic pathogens in DWDSs. For example, intracellular proliferation of Legionella pneumophila in Hartmannella vermiformis was observed in drinking water biofilms grown on plasticized polyvinyl chloride (Kuiper et al., 2004). It has also been reported that Mycobacterium spp. can enter and survive in the trophozoites and cysts of Acanthamoeba polyphaga (Adekambi et al., 2006). Therefore, investigation for eukaryotic communities is necessary to better understand the microbial ecology and potential health risk associated with pathogens in DWDSs. However, there have been few studies describing the eukaryotic diversity of DWDSs, and compared to studies on bacterial diversity, information is very scant.

In the present study, in order to give a better comprehension on microbial communities in DWDS biofilms, 454 pyrosequencing and quantitative PCR (qPCR) approaches were employed to characterize the community compositions of both bacteria and eukaryotes in the faucet biofilm samples.

\section{Materials and methods}

\subsection{Sampling and DNA extraction}

To analyze the impacts of different water qualities and biofilm ages on biofilm community, faucet biofilm samples were individually collected from three points (STZ, WSW and YJS, located at three biological laboratories) in two distribution systems in a northern city of China, in April, 2011. The faucets at sites STZ and YJS have been used for over 4 years, while that at site WSW for about 2 years. Water from sites STZ and WSW was supplied by one water plant, while water from site YJS was supplied by another plant. The biofilm samples were obtained from the surface of the rubber gaskets (outer diameter, $2.0 \mathrm{~cm}$; inner diameter, $1.0 \mathrm{~cm}$ ) within the faucets. Immediately after collection, the gaskets were transported to the lab and stored at $-20{ }^{\circ} \mathrm{C}$. Before the gasket was removed, the faucet was opened with a medium flow rate for approximately $5 \mathrm{~min}$, then about 101 of water samples was collected in sterilized brown glass bottles from each sampling site for water quality analysis. The water quality parameters analyzed and the values are listed in Table 1.

The biofilm samples were first scraped from the gaskets using sterile spatulas, and suspended with PBS buffer $\left(137 \mathrm{mmol} \mathrm{L}^{-1}\right.$ $\mathrm{NaCl}, 2.7 \mathrm{mmol} \mathrm{L}{ }^{-1} \mathrm{KCl}, 10 \mathrm{mmol} \mathrm{L}{ }^{-1} \mathrm{Na}_{2} \mathrm{HPO}_{4}, 2 \mathrm{mmol} \mathrm{L}{ }^{-1}$ $\mathrm{KH}_{2} \mathrm{PO}_{4}$ ). To ensure that all the biofilm samples were collected, the scraped gasket was then placed into a sterile centrifuge tube, and submerged in $5 \mathrm{~mL}$ PBS buffer. The tube was put into an ultrasonic bath, ultrasonicated at $40 \mathrm{kHz}$ for $15 \mathrm{~min}$, and the tubes were cooled in an ice bath every $2 \mathrm{~min}$. The obtained biofilm samples were collected together, and washed three times using PBS and centrifuged at $4{ }^{\circ} \mathrm{C}$, $10,400 \mathrm{~g}$, for $15 \mathrm{~min}$. After centrifugation, DNA was extracted using a FastDNA spin kit for soil (Qbiogene, Solon, $\mathrm{OH}$ ) facilitated with the FastPrep-24 bead beater system, following the manufacturer's instructions, and then quantified with a Nanodrop 1000 spectrophotometer (Thermo Scientific, Wilmington, DE).

\subsection{Enumeration of heterotrophic bacteria}

To roughly estimate the heterotrophic bacterium counts, the bacteria in $2 \mathrm{~L}$ of the water samples were harvested on $0.22 \mu \mathrm{m}$ pore-size Millipore GSWP filters by filtration and subsequently resuspended from the filter surface with 2 to $10 \mathrm{~mL}$ of physiological saline by vortexing, and then 0.05 to $0.1 \mathrm{~mL}$ aliquots were inoculated onto an LB agar medium. The plates were incubated aerobically at $37^{\circ} \mathrm{C}$ for $24 \mathrm{~h}$ to roughly determine the heterotrophic bacterium counts according to the drinking water standards of China (GB5749-85).

\subsection{Scanning electron microscopy}

The rubber gaskets taken from faucets were placed in a fixative that contained $2.5 \%$ glutaraldehyde $(\mathrm{w} / \mathrm{v})$ and $2.0 \%$ paraformaldehyde $(\mathrm{w} / \mathrm{v})$. The gaskets were fixed overnight, and were then washed three times ( 15 min each) with $\mathrm{dd}_{2} \mathrm{O}$. Samples were dehydrated by incubation in increasing concentrations of ethanol and then dried at the critical point with a $\mathrm{CO}_{2}$ critical point drier (Tousimis, MD). The gaskets were sputter coated with gold and viewed with a scanning electron microscope (SEM) (S-3000N, HITACHI, Japan).

\subsection{PCR and pyrosequencing}

The 16S rRNA genes of bacteria were amplified from genomic DNA using primers 27F [5'-AGA GTT TGA TCC TGG CTC AG-3', corresponding to Escherichia coli positions 8-27] and 533R [5'TTA CCG CGG CTG CTG GCA C-3', E. coli positions 515 to 533] (Lane, 1991; Weisburg et al., 1991). The 18S rRNA genes of eukaryotes were amplified using primers 3NDf [5'-GGC AAG TCT GGT GCC AG-3'] (Cavalier-Smith et al., 2009) and V4_euk_R2 [5'-ACG GTA TCT (AG)AT C(AG)T CTT CG-3'] (Bråte et al., 2010). Barcodes that allow sample multiplexing during pyrosequencing were incorporated in the $5^{\prime}$ end of primers 533R and 3NDf. PCR mixtures $(50 \mu \mathrm{L})$ were prepared in duplicate and each contained $1 \mu \mathrm{L}$ of DNA template, $5 \mu \mathrm{L}$ of 10 PCR buffer, $200 \mu \mathrm{M}$ of dNTP, $0.2 \mu \mathrm{M}$ of each primer and $2.5 \mathrm{U}$ Taq polymerase. The PCR reactions were performed with the following program: $94{ }^{\circ} \mathrm{C}$ for $5 \mathrm{~min}$; 20 cycles at $94{ }^{\circ} \mathrm{C}$ for $45 \mathrm{~s}, 56{ }^{\circ} \mathrm{C}$ for $45 \mathrm{~s}, 72{ }^{\circ} \mathrm{C}$ for $50 \mathrm{~s}$, and then $72{ }^{\circ} \mathrm{C}$ for $10 \mathrm{~min}$. Archaea were also amplified using primer sets Arch344f [5'-ACG GGG YGC AGC AGG CGC GA-3', E. coli positions 344 to 363] (Raskin et al., 1994) and Arch915 [5'-GTG CTC CCC

Table 1

Physicochemical properties of drinking water from each sampling site.

\begin{tabular}{|c|c|c|c|c|c|c|c|c|c|c|c|}
\hline Site & $\begin{array}{l}\text { Dissolved oxygen } \\
\left(\mathrm{mg} \mathrm{L}^{-1}\right)\end{array}$ & $\mathrm{pH}$ & $\begin{array}{l}\text { Temperature } \\
\left({ }^{\circ} \mathrm{C}\right)\end{array}$ & $\begin{array}{l}\text { Conductivity } \\
\left(\mu \mathrm{S} \mathrm{cm}^{-1}\right)\end{array}$ & $\begin{array}{l}\text { Free chlorine } \\
\left(\mathrm{mg} \mathrm{L}^{-1}\right)\end{array}$ & $\begin{array}{l}\text { Total residual chlorine }{ }^{a} \\
\left(\mathrm{mg} \mathrm{L}^{-1}\right)\end{array}$ & $\begin{array}{l}\text { Turbidity } \\
\left(\text { NTU }^{\mathrm{b}}\right)\end{array}$ & $\begin{array}{l}\operatorname{COD}^{\mathrm{c}} \\
\left(\mathrm{mg} \mathrm{L}^{-1}\right)\end{array}$ & $\begin{array}{l}\text { Total nitrogen } \\
\left(\mathrm{mg} \mathrm{L}^{-1}\right)\end{array}$ & $\begin{array}{l}\text { Total phosphate } \\
\left(\mathrm{mg} \mathrm{L}^{-1}\right)\end{array}$ & $\begin{array}{l}\operatorname{TDS}^{\mathrm{d}} \\
\left(\mathrm{mg} \mathrm{L}^{-1}\right)\end{array}$ \\
\hline STZ & 7.5 & 7.51 & 20 & 403 & 0.02 & 0.09 & $<0.5$ & 0.4 & 1.22 & 0.01 & 302 \\
\hline WSW & 6.9 & 8.06 & 28 & 405 & 0.02 & 0.08 & $<0.5$ & 0.4 & 1.34 & 0.02 & 314 \\
\hline YJS & 7.5 & 8.01 & 22 & 1100 & $\mathrm{ND}^{\mathrm{e}}$ & ND & $<0.5$ & 0.4 & 17.2 & 0.01 & 852 \\
\hline
\end{tabular}

Values are means of triplicates.

a Values of residual chlorine are means of data determined throughout April to June, 2011.

b NTU, nephelometric turbidity units.

c COD, chemical oxygen demand.

d TDS, total dissolved solid.

e ND, not detected. 
CGC CAA TTC CT-3', E. coli positions 915 to 934] (Stahl and Amann, 1991). The Archaeal amplification was performed using the genomic DNA extracted from anaerobic active sludge as a positive control, but no PCR product was obtained from the biofilm DNA samples. The PCR products of bacteria and eukaryotes were purified and then sequenced by pyrosequencing method on a 454 Life Sciences Genome Sequencer FLX (Roche Diagnostics, Indianapolis, IN, USA) machine. Sequences and quality scores from the pyrosequencing run were submitted to the NCBI short read archive (accession number SRA048160).

\subsection{Phylogenetic and statistical analyses}

After sequencing was completed, all sequence reads were quality checked using Mothur software (Schloss et al., 2009). Any poor quality reads were removed. Raw sequence reads were filtered before subsequent analyses to minimize the effects of random sequencing errors. Briefly, we eliminated sequence reads that did not perfectly match the proximal PCR primer, were less than 200 bp for bacteria and $400 \mathrm{bp}$ for eukaryotes, contained one or more ambiguous base(s), or checked as chimeric artifact. The rest of the sequences were trimmed and classified using Bayesian approach with the Silva database (Pruesse et al., 2007 ) as template, and a cutoff of $80 \%$. Mothur was also used to conduct rarefaction analysis, construct the distance matrices, assign sequences to operational taxonomic units (OTUs, 97\% similarity) and calculate Good's coverage, abundance based coverage estimator (ACE), Chao1 richness estimator and Shannon diversity indices. The Mann-Whitney test and categorical principal component analysis were performed by using the SPSS version 16.0 release.

\subsection{Quantitative PCR assay}

The abundance of bacterial and eukaryotic small-subunit rRNA genes was estimated by qPCR analysis using Eub341F and Eub533R primers for bacteria and 3NDf and V4_euk_R2 for eukaryotes. The standard plasmids carrying target genes were obtained by TA cloning and extracted using a TIANpure Mini Plasmid kit (Tiangen, China). The $25 \mu \mathrm{L}$ reactions typically contained $1 \times$ Sybr Green I, $1 \times$ dye (Takara, Dalian, China), $200 \mathrm{nM}$ of each primer, $0.5 \mathrm{mg} \mathrm{mL}^{-1} \mathrm{BSA}$, and $2 \mu \mathrm{L}$ of properly diluted DNA templates. Real-time PCR was run using an ABI7300 apparatus (ABI, USA) by the 4-step program: $95{ }^{\circ} \mathrm{C}$ for $30 \mathrm{~s}, 40$ cycles consisted of: (i) $95{ }^{\circ} \mathrm{C}$ for $10 \mathrm{~s}$, (ii) annealing temperature for $15 \mathrm{~s}$, (iii) $72{ }^{\circ} \mathrm{C}$ for $15 \mathrm{~s}$, and (iv) $78{ }^{\circ} \mathrm{C}$ for $26 \mathrm{~s}$ to collect the fluorescent signals, and finally the melting process was automatically generated by the ABI7300 software. Triplicates of serially diluted standard plasmids were performed to obtain the standard curves. Duplicates of samples and negative controls were performed for quantification.

\section{Results and discussion}

\subsection{Water quality}

The water quality of potable water at sites STZ and WSW, which is supplied by the same water plant, was similar to each other, with the exception of dissolved oxygen (DO), $\mathrm{pH}$ and temperature (Table 1 ). In contrast, the water from site YJS, which is supplied by another water plant differed in several respects from the other two water samples. The conductivity, total nitrogen (TN), and total dissolved solid (TDS) levels in YJS water samples were obviously higher than those in the others. The chlorine levels at each site were relatively stable throughout April to June. Although drinking water has been treated with chlorination before entering into the distribution system, free chlorine and total chlorine were not detected in the YJS water samples. Residual chlorine is normally consumed in the delivery process, and the high level of TDS in the YJS water may exacerbate the dissipation of effective chlorine (Li et al., 2010). The heterotrophic bacterium counts were
$(1.6 \pm 0.3) \times 10^{4} \quad\left(\right.$ mean \pm standard deviation), $(3.9 \pm 0.5) \times 10^{2}$, and $(6.8 \pm 0.8) \times 10^{2} \mathrm{CFU} \mathrm{L}^{-1}$ in the YJS, STZ and WSW water samples, respectively. The bacterial cell numbers in the YJS water samples were significantly higher than that in the others (Mann-Whitney $U$ test, $\mathrm{P}<0.03$ ), which might be associated with the lack of disinfectants. Nevertheless, the water values were determined from limited samples at one point in time (except residual chlorine in water), and may not represent the conditions for the entire period when the biofilm was forming.

\subsection{Morphology and microbial abundance in the faucet biofilms}

To confirm bacterial growth in the faucets, the rubber gaskets taken from the faucets were observed by a scanning electron microscope (SEM). SEM analysis of the gaskets revealed that dense and thick biofilms formed at sites STZ and YJS, coated with a large amount of extracellular matrix material (Fig. 1). The matrix material was also observed previously in the biofilms developed on the surface of a plastic substratum in water meters and showerheads (Feazel et al., 2009; Hong et al., 2010). It is found that polysaccharides increased in the biofilm with aging (Batte et al., 2003). Obviously different morphologies of biofilm were observed at site WSW, where sparse populations of mainly short, rod-shaped organisms attached on the gasket with low cell density, showing the morphological characteristics of early biofilm formation (Martiny et al., 2003).

The biomass of bacteria and eukaryotes was estimated by quantitative PCR using primers specific for bacterial and eukaryotic rRNA genes. The qPCR assays showed that bacteria were numerically dominant in the faucet biofilm microbiota, with a 16S/18S rRNA gene ratio of 100:2 for the WSW biofilm, and 100:6 for the STZ and YJS biofilms. The number of bacterial 16S rRNA gene copies in the rubber gaskets at sites STZ and YJS $\left(3.84 \times 10^{6}\right.$ and $9.78 \times 10^{6}$, respectively) was higher than that at site WSW $\left(5.88 \times 10^{4}\right)$ by about two orders of magnitude, indicating that the bacterial biomass in the WSW biofilm is relatively low. This is consistent with the observations by SEM.

\subsection{Microbial diversity and richness}

To give a comprehensive insight into microbial communities in faucet biofilms, the rRNA gene sequences of bacteria, archaea, and eukaryota were amplified using universal primer pairs 27F/533R, Arch344F/Arch915, and 3NDf/V4_euk_R2, respectively. Archaeal DNA was not successfully amplified from the biofilm samples. Finally, a total of 46,169 bacterial and 49,760 eukaryotic raw sequence reads were generated from the PCR amplicons by 454 pyrosequencing. The filtering process removed about $1 / 4$ of raw bacterial reads and $1 / 3$ of raw eukaryotic reads, leaving 33,092 high-quality bacterial ( $\geq 200 \mathrm{bp}$, average length of about $470 \mathrm{bp}$ ) and 34,370 eukaryotic sequence reads ( $\geq 400 \mathrm{bp}$, average length of about $464 \mathrm{bp}$ ). After chimera check and removing obviously erroneous reads (sequences classified as chloroplast and those not classified into bacterial or eukaryotic domain), 22,736 validated bacterial and 33,704 eukaryotic reads were performed for further phylogenetic analysis.

The diversity and richness indices were calculated at a $3 \%$ width, as shown in Table 2. The faucet biofilms showed a large bacterial diversity, with Shannon diversity indices (3.45-4.52) comparable to some derived from river water or even soil. A total of 148 genera were identified by using the Bayesian method with a stringent cutoff of $80 \%$, as listed in Table 3. In comparison to other investigations for water supply systems using molecular methods, e.g. clone library, metagenome, in situ hybridization (Manz et al., 2000; Schmeisser et al., 2003; Williams et al., 2004), the phylogenetic analysis of pyrosequencing 16S rRNA gene sequences demonstrated a more diverse bacterial genus in the DWDS biofilms. In contrast, the diversity and richness of eukaryotes in biofilm samples was low, with the Shannon values of 1.05-3.07. Among the 


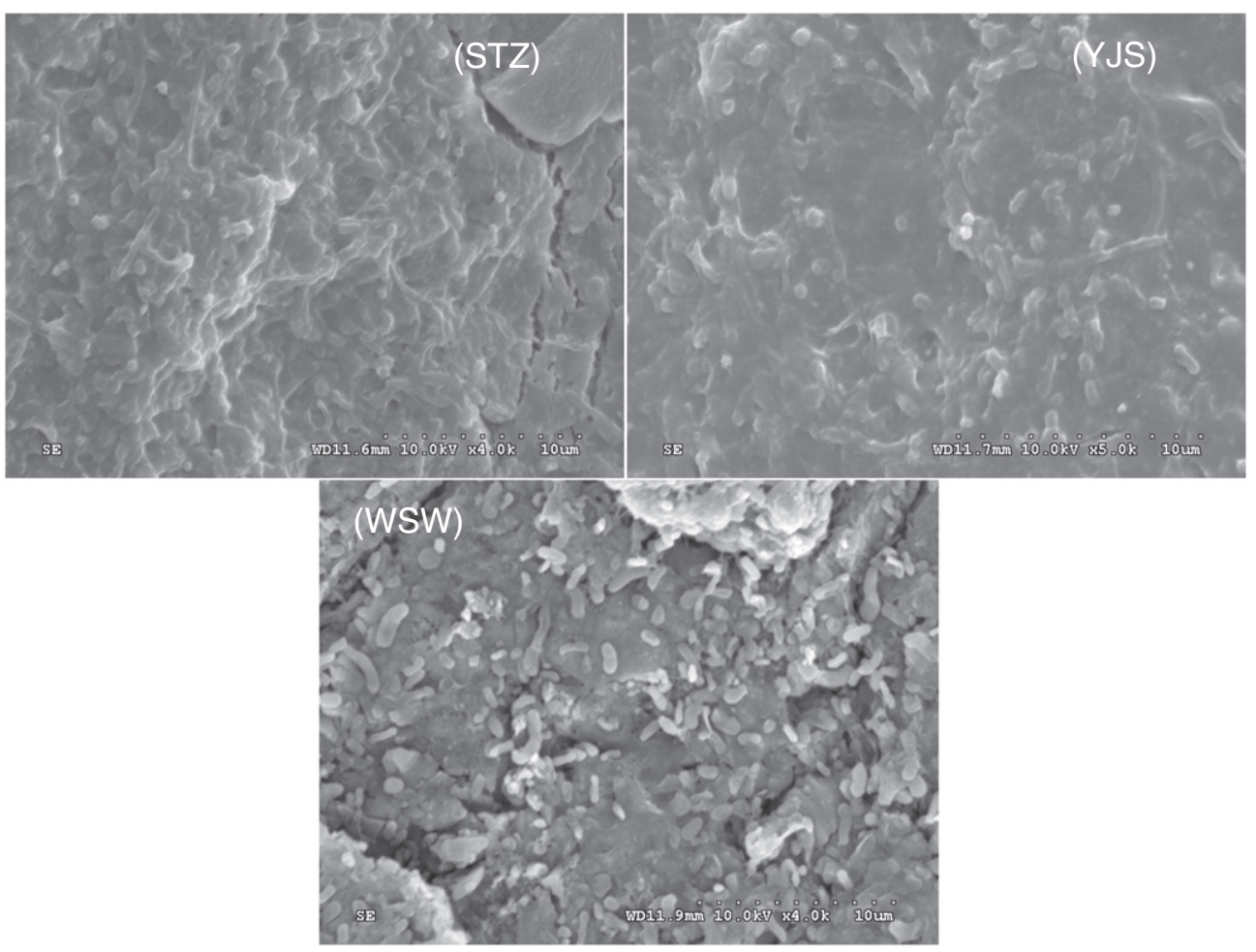

Fig. 1. The SEM images of the gaskets.

three biofilms, the diversity of bacteria and eukaryotes in the WSW biofilm was markedly higher than in the others. The coverage of the sequence libraries based on pyrosequencing was high, ranging from 93.1 to $99.7 \%$.

\subsection{Eukaryotic communities}

In view of the close association of eukaryotes with biofilm bacterial community and proliferation of some waterborne pathogens, the eukaryotic communities of the faucet biofilms were investigated by pyrosequencing in the present study. Although the water qualities were different in many aspects, biofilms at sites STZ and YJS showed more similar eukaryotic community structures (Fig. 2B), with Amoebozoa as the most primary group, comprising $87.66 \%$ and $88.75 \%$ of eukaryotic sequence reads respectively, followed by fungi (1.93\% and 2.88\%) (Fig. 3B). Among the phylum Amoebozoa, $H$. vermiformis was the dominant species. However, no Amoebozoarelated sequences were identified in the WSW biofilm. The majority of WSW sequences were distributed into Metazoa (40.56\%), fungi (33.76\%) and Viridiplantae (22.07\%). The fungi found in all three biofilm samples were mainly Pezizomycotina species.

The notable characteristic of the YJS and STZ eukaryotic communities was the high abundance of Hartmannella species, most of which were closely related to $H$. vermiformis. The $18 \mathrm{~S}$ rRNA genes of $H$. vermiformis are organized in tandem repeat units, with about 1330 copies per cell (Kuiper et al., 2006). Thus, based on the relative scale of $H$. vermiformis in eukaryotic communities and eukaryotic qPCR results, we calculated that about 150 and $410 \mathrm{H}$. vermiformis cells per rubber gasket were present at sites STZ and YJS, respectively. Interestingly, none of the sequences retrieved from the WSW biofilm was classified as amoeba. This phenomenon should be associated with the low bacterial biomass of the WSW biofilm (about two orders of magnitude of 16S rRNA gene copies lower than the others). Principal component analysis (PCA) showed that the appearance of Hartmannella correlated closely with the bacterial biomass of the biofilms (Fig. 4). Modeling of data from a biofilm-batch model indicated that amoebae can only multiply when a threshold concentration of prey bacteria is reached (Kuiper, 2006). Valster et al. $(2009,2011)$ indicated that the growth of $H$. vermiformis in drinking water distribution systems is limited at low biofilm concentrations or at ATP concentrations of $\leq 1 \mathrm{ng} \mathrm{L}^{-1}$.

A number of eukaryotic sequences from the WSW biofilm were related to those of species unlikely to live in biofilm systems, such as Arthropoda and Chordata in Metazoa, and Spermatophyta in Viridiplantae. Because DNA-based approaches could not differentiate between dead and live cells in the environments, it is difficult to get a true profile of indigenous eukaryotes under the interference of exogenous 18S rRNA gene. To resolve this issue, RNA targeting assays may be promising, which have been used to study active bacterial communities in bulk

Table 2

Coverage and diversity indices of bacterial and eukaryotic communities.

\begin{tabular}{|c|c|c|c|c|c|c|c|}
\hline & OTUs $^{a}$ & $S_{\text {chao1 }}$ & $S_{\text {ACE }}$ & Shannon & Evenness & No. of reads ${ }^{b}$ & Coverage (\%) \\
\hline STZ (eukaryotes) & 297 & 967 & 1690 & 1.05 & 0.18 & 11,213 & 98.2 \\
\hline WSW (eukaryotes) & 102 & 172 & 183 & 3.03 & 0.66 & 10,948 & 99.7 \\
\hline YJS (eukaryotes) & 265 & 662 & 1102 & 1.03 & 0.19 & 11,543 & 98.6 \\
\hline STZ (bacteria) & 363 & 724 & 1159 & 3.44 & 0.58 & 6191 & 96.8 \\
\hline WSW (bacteria) & 1564 & 2430 & 2445 & 4.49 & 0.61 & 13,351 & 94.7 \\
\hline YJS (bacteria) & 356 & 1050 & 1612 & 3.92 & 0.67 & 3194 & 93.1 \\
\hline
\end{tabular}

a The operational taxonomic units (OTU) were determined with a $3 \%$ width.

b Trim reads that passed quality controls. 
Table 3

Identified bacterial genera in the faucet biofilm communities.

\begin{tabular}{|c|c|c|c|c|c|c|c|c|c|c|c|}
\hline \multirow[t]{2}{*}{ Genus } & \multicolumn{3}{|c|}{ Sampling site } & \multirow[t]{2}{*}{ Genus } & \multicolumn{3}{|c|}{ Sampling site } & \multirow[t]{2}{*}{ Genus } & \multicolumn{3}{|c|}{ Sampling site } \\
\hline & WSW & STZ & YJS & & WSW & STZ & YJS & & WSW & STZ & YJS \\
\hline Acidovorax & $14.22^{\mathrm{a}}$ & - & 3.85 & Flavobacterium & 0.22 & - & 0.09 & Panacagrimonas & 0.02 & - & - \\
\hline Acinetobacter & 2.34 & - & 0.09 & Flexibacter & 0.16 & 1.34 & 16.03 & Pandoraea & 0.01 & - & - \\
\hline Actinoplanes & 0.07 & - & - & Frigoribacterium & 0.04 & - & - & Paracoccus & 0.16 & 0.08 & - \\
\hline Adhaeribacter & 0.01 & - & - & Fusobacterium & - & 0.02 & - & Pedomicrobium & 0.09 & - & - \\
\hline Aeromicrobium & 0.04 & - & - & Gemmata & 0.06 & 3.73 & 0.19 & Pelomonas & 0.03 & - & - \\
\hline Afipia & - & 0.05 & - & Gemmatimonas & 1.34 & 0.15 & 1.28 & Peptoniphilus & 0.05 & - & - \\
\hline Alcaligenes & 0.01 & - & - & Geobacillus & 0.01 & - & - & Phenylobacterium & 0.16 & 0.32 & 0.91 \\
\hline Amaricoccus & 0.07 & - & - & Geodermatophilus & 0.07 & - & 0.03 & Phyllobacterium & 0.01 & - & - \\
\hline Aminobacter & 0.03 & - & - & Hydrogenophaga & 0.03 & - & - & Pirellula & 0.12 & - & - \\
\hline Amycolatopsis & 0.01 & - & - & Hymenobacter & 0.02 & - & - & Planctomyces & 0.11 & - & - \\
\hline Anaerolinea & 0.02 & - & - & Hyphomicrobium & 0.50 & 0.50 & - & Polaromonas & 0.03 & - & - \\
\hline Aquabacterium & 0.03 & 7.51 & 25.02 & Ilumatobacter & 0.02 & - & - & Porphyrobacter & 6.96 & - & - \\
\hline Aquicella & 0.02 & - & - & Janthinobacterium & 0.04 & - & - & Porphyromonas & 0.02 & - & - \\
\hline Arthrobacter & 0.15 & - & - & Kocuria & 0.04 & - & - & Prevotella & 0.01 & - & - \\
\hline Azospira & 0.01 & - & - & Labrys & 0.11 & - & - & Propionibacterium & 0.86 & - & - \\
\hline Bacillus & 0.04 & - & - & Lacibacter & - & 0.02 & - & Prosthecobacter & - & - & 0.13 \\
\hline Balneimonas & 0.01 & - & - & Legionella $^{\mathrm{b}}$ & 0.01 & 0.06 & 1.00 & Pseudolabrys & 0.01 & - & - \\
\hline Blastococcus & 0.03 & - & - & Lentzea & 0.06 & - & - & Pseudomonas & 0.24 & - & 1.57 \\
\hline Blastomonas & 20.99 & 0.03 & 0.03 & Leptolyngbya & 0.01 & - & - & Pseudorhodoferax & 0.25 & - & - \\
\hline Bosea & 0.04 & 0.10 & - & Leptospira ${ }^{\mathrm{b}}$ & - & - & 0.78 & Pseudoxanthomonas & 0.04 & 0.02 & 0.25 \\
\hline Brachybacterium & 0.01 & - & - & Leucobacter & 0.03 & - & - & Psychrobacter & 0.07 & - & - \\
\hline Brachymonas & 0.02 & - & - & Limnobacter & 0.02 & - & - & Ralstonia & 0.06 & - & - \\
\hline Bradyrhizobium & 0.88 & 0.13 & - & Lutispora & 0.02 & - & - & Rhizobium & 0.10 & - & - \\
\hline Brevundimonas & 0.04 & - & - & Lysobacter & 0.02 & - & - & Rhodanobacter & 2.82 & - & - \\
\hline Bryobacter & - & 0.50 & - & Marmoricola & 0.04 & - & - & Rhodobacter & - & 0.90 & 0.88 \\
\hline Caenimonas & 0.37 & - & - & Massilia & 0.04 & - & - & Rhodoplanes & 0.04 & - & - \\
\hline Caldilinea & 0.03 & - & - & Mesorhizobium & 0.15 & - & - & Rickettsia ${ }^{\mathrm{b}}$ & 0.02 & - & - \\
\hline Campylobacter $^{\mathrm{b}}$ & 0.03 & - & - & Methylibium & - & - & 0.03 & Roseiflexus & 0.37 & - & - \\
\hline Candidatus_Odyssella & - & - & 0.09 & Methylobacterium & 2.16 & 0.19 & 0.25 & Roseomonas & 0.01 & - & - \\
\hline Caulobacter & 0.17 & 0.03 & 0.06 & Methylophilus & 0.15 & 0.02 & - & Rothia & 0.09 & - & - \\
\hline Chryseobacterium & 0.01 & - & - & Methyloversatilis & 0.01 & 0.13 & 0.19 & Sediminibacterium & 0.04 & 4.47 & 0.06 \\
\hline Clostridium & 0.19 & - & - & Microbacterium & 0.10 & - & - & Singulisphaera & 0.01 & - & - \\
\hline Comamonas & 0.22 & - & - & Micrococcus & 0.04 & - & - & Skermanella & 0.08 & - & - \\
\hline Corallococcus & 0.02 & - & - & Microcoleus & 0.10 & - & - & Sphaerobacter & 0.01 & - & - \\
\hline Corynebacterium & 0.13 & - & - & Mucilaginibacter & 0.07 & - & - & Sphingobacterium & 0.02 & - & - \\
\hline Crenothrix & 0.01 & - & - & Mycobacterium $^{\mathrm{b}}$ & 1.29 & 3.59 & 0.03 & Sphingobium & 0.28 & 0.97 & 9.64 \\
\hline Cupriavidus & 0.01 & - & - & Neisseria & 0.05 & - & - & Sphingomonas & 5.22 & 0.05 & 2.50 \\
\hline Dechloromonas & - & - & 0.06 & Niabella & 0.01 & - & - & Sphingopyxis & 0.03 & 4.85 & 0.88 \\
\hline Deinococcus & 0.07 & - & - & Nitrosomonas & - & 0.02 & - & Staphylococcus & 0.09 & - & - \\
\hline Delftia & 0.01 & - & - & Nitrospira & 0.46 & 2.49 & 0.06 & Stenotrophomonas & 0.01 & - & - \\
\hline Desulfomonile & 0.01 & - & - & Nocardia & 0.03 & - & - & Steroidobacter & 0.24 & - & - \\
\hline Devosia & 0.12 & - & - & Nocardioides & 0.07 & - & - & Streptococcus & 0.03 & - & - \\
\hline Diaphorobacter & 0.01 & - & - & Nocardiopsis & 0.04 & - & - & Streptomyces & 0.07 & - & - \\
\hline Dyella & 0.10 & - & - & Nordella & 0.13 & - & - & Syntrophorhabdus & 0.02 & - & - \\
\hline Enhydrobacter & 0.10 & - & - & Novosphingobium & 0.13 & 0.76 & 6.95 & Terrabacter & 0.06 & - & - \\
\hline Ensifer & 0.03 & - & - & Ochrobactrum & 0.73 & 0.02 & - & Thiobacillus & 0.01 & - & 0.47 \\
\hline Enterobacter $^{\mathrm{b}}$ & 0.04 & - & - & Ornithinimicrobium & 0.04 & - & - & Tsukamurella & 0.01 & - & - \\
\hline Enterococcus & 0.01 & - & - & Ottowia & 0.38 & - & - & Ureibacillus & 0.07 & - & - \\
\hline Escherichia-Shigella ${ }^{\mathrm{b}}$ & 0.24 & - & - & Paenibacillus & 0.04 & - & - & Variovorax & 0.02 & - & - \\
\hline Ferruginibacter & 0.14 & - & 0.31 & & & & & & & & \\
\hline
\end{tabular}

a Bacterial abundance of $\geq 1 \%$ is in bold.

b Potential pathogenic bacterial genus.

water and drinking water biofilm (Keinanen-Toivola and Revetta, 2006; Revetta et al., 2010).

\subsection{Bacterial communities}

Like the eukaryotic communities, bacterial communities at sites STZ and YJS also showed more similar compositions to each other than that at site WSW (Fig. 2A). Seven bacterial taxa were detected in all three biofilm samples, i.e. Proteobacteria, Acidobacteria, Bacteroidetes, Planctomycetes, Actinobacteria, Nitrospirae, and Gemmatimonadetes (Fig. 3A). The bacterial diversity of the WSW biofilm was considerably rich in phylum level, with thirteen unique taxa but comprising a small proportion of sequence reads ( $2.79 \%$ of sequence reads). The phyla Spirochaetes and Verrucomicrobia were only detected in the STZ biofilm.

In agreement with previous studies, Proteobacteria were the primary bacterial group in all biofilm samples, comprising 65.84\%$77.51 \%$ of pyrosequencing reads, within which Alphaproteobacteria and Betaproteobacteria (38.79-54.77\% and $10.64-33.09 \%$ of sequence reads, respectively) were the dominant groups. Furthermore, most of the OTUs ( 13 of 14 OTUs) shared by all samples representing 7244 sequences were classified into the two classes. These demonstrated the importance of Alphaproteobacteria and Betaproteobacteria in oligotrophic DWDS ecosystems. The majority of Alphaproteobacteria sequences belonged to the orders Sphingomonadales (18.58-38.67\%) and Rhizobiales (6.20-29.12\%), and mainly classified into the genera Bradyrhizobium, Blastomonas, Methylobacterium, Novosphingobium, Porphyrobacter, Sphingobium, Sphingomonas, and Sphingopyxis, most members of which are common residents of fresh water habitats or potable water distribution systems (Hong et al., 2010; Liu et al., 2012; Simoes et al., 2008). Many Sphingomonadales bacteria can produce abundant exopolysaccharides, lack special growth requirements, and resist to chlorine (Furuhata et al., 2007), characteristics which conferred an ecological advantage for their growth and formation of stable biofilms in oligotrophic environments (White et al., 
A

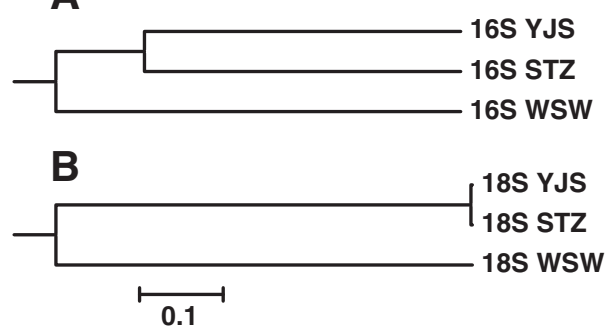

Fig. 2. Bacterial (A) and eukaryotic (B) community clustering based on the 16/18S rRNA gene pyrosequencing reads using the thetayc calculator of Mothur software.

1996). The Betaproteobacteria sequences were mainly affiliated within the family Comamonadaceae in Burkholderiales. Within the Comamonadaceae, Acidovorax spp. (14.22\%) predominated in the WSW biofilm while Aquabacterium spp. was abundant in the STZ (7.51\%) and YJS (25.02\%) biofilms, which was a widespread bacterial species in drinking water biofilms (Manz et al., 2000).

Acidobacteria was the second largest bacterial group (10.21\%) in the STZ biofilm community, other major groups ( $>2 \%$ of sequence reads) include the phyla Bacteroidetes (8.38\%), Planctomycetes (6.48\%), Actinobacteria (3.75\%), and Nitrospirae (2.49\%). In contrast, Actinobacteria (4.87\%) was the second most dominant group in the WSW biofilm, followed by Acidobacteria (2.98\%), while the nonproteobacteria sequences from site YJS were mainly affiliated within Bacteroidetes (16.5\%).

In this study, although the water quality at site YJS was different with those at sites WSW and STZ (Table 1) in many aspects, interestingly, the microbial community of the WSW biofilm was distinctly separated from the others (Fig. 2). Within the WSW biofilm community, microbial diversity was markedly higher than the others (Table 2), and a notable microbial characteristic was the abundance of sequences related to Blastomonas natatoria (20.99\%) and Acidovorax spp. (14.22\%).

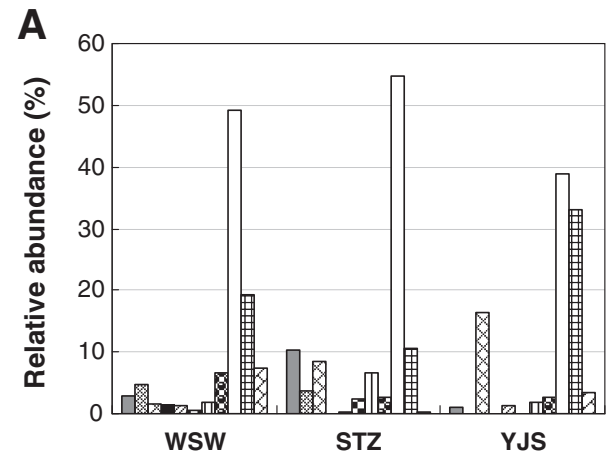

$\square$ Acidobacteria Actinobacteria Bacteroidetes - Chloroflexi $\checkmark$ Gemmatimonadetes Nitrospirae प Planctomycetes Unclassified $\square$ Alphaproteobacteria 田 Betaproteobacteria 囚 Gammaproteobacteria

\section{B}

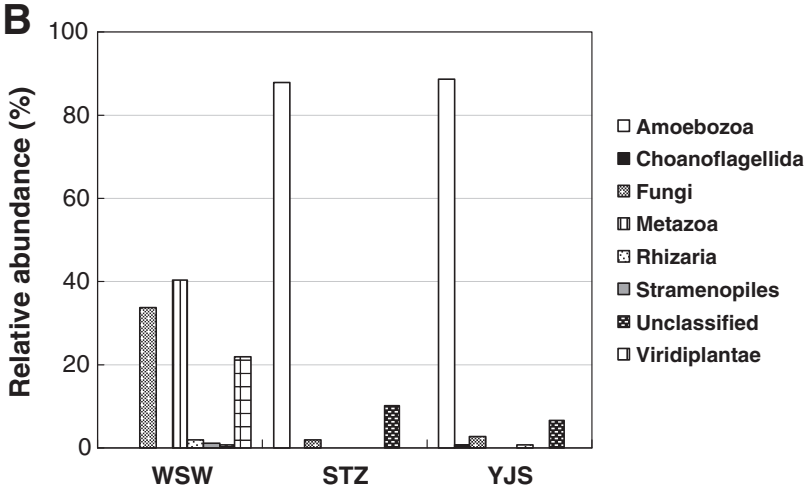

Fig. 3. Richness and abundance distribution of bacterial (A) and eukaryotic (B) populations in the biofilm samples. The taxonomic group whose abundance is $<1 \%$ in all three biofilm communities was not shown.

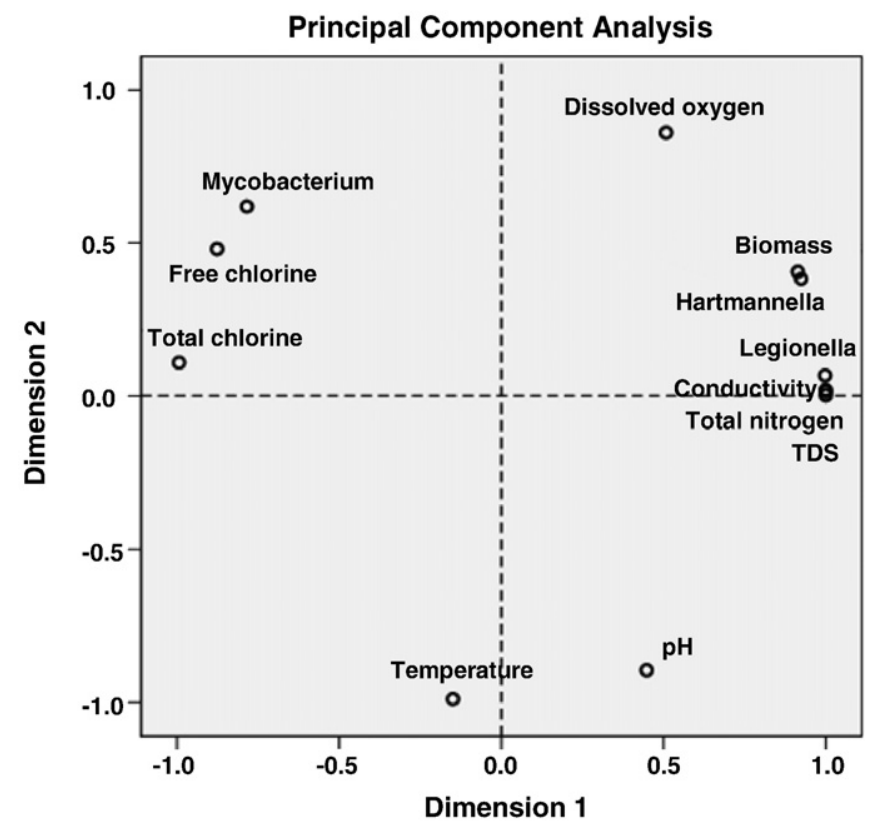

Fig. 4. Principal component analysis of water quality parameters, bacterial biomass (represented by the number of $16 \mathrm{~S}$ rRNA gene copies), calculated number of Hartmannella vermiformis, and abundance of Mycobacterium and Legionella in the biofilm communities. Dimension 1 explained $71.1 \%$ of the observed variation; dimension 2 explained $28.9 \%$ of the variation.

B. natatoria cell has a mucilaginous holdfast at its non-reproductive pole, by which it can attach to solid surfaces or other cells. It is reported that $B$. natatoria can coaggregate with other biofilm bacteria, an ability that may be advantageous to colonization and pioneer biofilm formation (Rickard et al., 2000). Some Acidovorax species isolated from freshwater biofilm communities showed strong autoaggregating abilities, and possessed high whole-cell hydrophobicity which can enhance the autoaggregation interactions. And it is suggested that aggregating abilities and whole-cell hydrophobicity are important for colonization and biofilm development in flowing environments (Rickard et al., 2004). Biofilm formation in oligotrophic drinking water environments also could be viewed as a successional process in structure and species compositions (Martiny et al., 2003). Due to the stochastic attachment of a number of species from the bulk water at early stages of biofilm formation, a young biofilm always has a high level of microbial diversity but low biomass. And the young and old DWDS biofilms may possess significantly different microbial compositions (Martiny et al., 2003). Considering the high diversity, low biomass, sparse organism colonization, and abundant aggregating bacteria, it is suggested that the biofilm at site WSW should still be at the early stages of biofilm formation, and that may be responsible for the distinct separation of the WSW biofilm community from the others.

\subsection{Potential bacterial pathogens}

Several potential waterborne pathogenic genera (WHO, 2008) were simultaneously identified from the faucet biofilms by the pyrosequencing method (Table 3). Notably, Legionella and Mycobacterium were found in all three biofilm samples. Due to the complex cell wall, mycobacteria are generally resistant to several disinfectants, e.g. chlorine, chloramines (Vaerewijck et al., 2005). The resistance confers their selective advantage for natural competence in chlorine-containing DWDSs. Mycobacteria often occur in biofilms that form in water supply systems, and have been found in two urban DWDS biofilms in China (Liu et al., 2012). In the present study, sequences indicative of Mycobacterium were abundant in the WSW (1.29\%) and STZ (3.53\%) biofilms compared to the YJS biofilm (0.03\%). PCA analysis showed that residual chlorine correlated closely 
with the abundance of mycobacteria (Fig. 4), suggesting that chlorine may facilitate the heavy occurrence of mycobacteria in faucet biofilms. Many of the Mycobacterium-related sequences (297 sequences) cannot be classified at the species level, while some Mycobacterium sequences (70 sequences) were closely related to $M$. lentiflavum, which has been isolated from drinking water systems, and may infect immunocompromised people.

In comparison with mycobacteria, Legionella spp. are more susceptible to residual chloride in portable water, whereas incorporation of Legionella bacteria into potable water biofilm or intracellular growth within amoeba, particularly $H$. vermiformis, were frequently reported to provide protective niches against chlorination stress, and were essential for their proliferation in DWDS biofilms (Giao et al., 2009; Kuiper et al., 2004; Percival and Walker, 1999). However, few Legionella-related sequences were detected in the STZ and WSW communities ( 4 and 1 sequence reads, respectively), despite the low level of free chlorine $\left(0.02 \mathrm{mg} \mathrm{L}^{-1}\right)$, and the presence of abundant $H$. vermiformis relatives at site STZ. In contrast, a number of Legionella-related sequences (1.00\% of sequences) were detected at site YJS where no chlorine was detected, and showed high similarity to Legionella anisa which may cause Pontiac fever. There was no obvious promoting role of biofilm and Hartmannella of amoeba for the growth of Legionella observed in the current study, but PCA analysis showed that residual chlorine in water was negatively associated with Legionella bacteria (Fig. 4). The Legionella species within the STZ biofilm may be not associated with intracellular life with amoeba. It has been reported that even if there are different serogroups of $L$. pneumophila, different behaviors were observed both in colonizing the experimental water system and in co-culture with amoeba (Messi et al., 2011). Overall, chlorine seems to be a dominant factor impacting the abundance distribution of Legionella spp. and Mycobacterium spp. in the faucet biofilms.

\subsection{Potential bacterial functional groups}

In terms of functional groups, nitrifier-related sequences were identified in all faucet biofilms. The ammonia oxidizer relatives were only detected at sites STZ and WSW, and were affiliated within the family Nitrosomonadaceae. Nitrite-oxidizer relatives were mainly closely related to Nitrospira moscoviensis. Members of the family Nitrosomonadaceae and the genus Nitrospira have been found in pilot- and full-scale DWDSs as the primary nitrifiers (Lipponen et al., 2004; Regan et al., 2002, 2003). The number of potential nitrifiers was higher at chlorine-containing sites (WSW and STZ). This was generally concordant with those of previous reports that chloramination or chlorination of the drinking water may promote growth of nitrifying bacteria (Eichler et al., 2006; Martiny et al., 2005). Besides, denitrifier-related sequences were identified in the WSW biofilm, and closely related to Brachymonas denitrificans and Comamonas denitrificans. In the study of a red water event, we also detected denitrifier relatives in the same water supply system using the Sanger clone sequencing method (Li et al., 2010).

\section{Conclusions}

In this study, both eukaryotic and bacterial communities of the faucet biofilms were revealed by high through-put pyrosequencing and qPCR approaches. Although the biofilm at site WSW has been developed for about 2 years, its microbial community still shows the characteristics of a young biofilm community (e.g. low biomass and abundant aggregating bacteria), and distinctly separated from the others. Therefore, to understand the variations of biofilm microbial populations in relation to water geochemistry, disinfection strategy applied, or pipe materials, the impact of the stage of biofilm formation must be fully considered. On the other hand, Hartmannella of amoebae was the dominant eukaryotic predator in the biofilm, and correlated closely with biofilm bacterial biomass. However, no obvious association of pathogens with amoebae was observed in the faucet biofilms. Residual chlorine in water seems to be the primary impact factor of the abundance of Legionella and Mycobacterium, two primary potential opportunistic pathogens detected in all faucet biofilms. The ecology of bacterial pathogen-protozoon interactions still needs further study, especially in the large-scale DWDSs.

The present study lends light on the comprehensive analysis of the compositions of both bacterial and eukaryotic DWDS biofilm communities in the genus level using 454 pyrosequencing. However, gaining a thorough knowledge of the variations of microbial community during biofilm formation, and the complex interactions between different biofilm microfloras will need a longitudinal study, more sampling sites, and analysis for active communities in future researches. Such studies will help better characterize the microbial ecology in DWDSs and provide insights into treatment efficacy for drinking waters.

\section{Acknowledgments}

This work was funded by the Knowledge Innovation Project of the Chinese Academy of Science (Y025014EA2), the China Postdoctoral Science Foundation (2012M510592), and the Dean Fund of Graduate University of Chinese Academy of Sciences 2011B (Y15102FN00).

\section{References}

Adekambi T, Ben Salah S, Khlif M, Raoult D, Drancourt M. Survival of environmental mycobacteria in Acanthamoeba polyphaga. Appl Environ Microbiol 2006;72:5974-81.

Batte M, Koudjonou B, Laurent P, Mathieu L, Coallier J, Prevost M. Biofilm responses to ageing and to a high phosphate load in a bench-scale drinking water system. Water Res 2003;37:1351-61.

Berry D, Xi C, Raskin L. Microbial ecology of drinking water distribution systems. Curr Opin Biotechnol 2006;17:297-302.

Bråte J, Logares R, Berney C, Ree DK, Klaveness D, Jakobsen KS, et al. Freshwater Perkinsea and marine-freshwater colonizations revealed by pyrosequencing and phylogeny of environmental rDNA. Isme J 2010;4:1144-53.

Buswell CM, Herlihy YM, Lawrence LM, McGuiggan JT, Marsh PD, Keevil CW, et al. Extended survival and persistence of Campylobacter spp. in water and aquatic biofilms and their detection by immunofluorescent-antibody and -rRNA staining. Appl Environ Microbiol 1998;64:733-41.

Cavalier-Smith T, Lewis R, Chao EE, Oates B, Bass D. Helkesimastix marina n. sp. (Cercozoa: Sainouroidea superfam. n.) a gliding zooflagellate of novel ultrastructure and unusual ciliary behaviour. Protist 2009;160:452-79.

Eichler S, Christen R, Holtje C, Westphal P, Botel J, Brettar I, et al. Composition and dynamics of bacterial communities of a drinking water supply system as assessed by RNA- and DNA-based 16S rRNA gene fingerprinting. Appl Environ Microbiol 2006;72:1858-72.

Feazel LM, Baumgartner LK, Peterson KL, Frank DN, Harris JK, Pace NR. Opportunistic pathogens enriched in showerhead biofilms. Proc Natl Acad Sci U S A 2009;106: 16393-8.

Furuhata K, Kato Y, Goto K, Saitou K, Sugiyama J, Hara M, et al. Identification of yellow-pigmented bacteria isolated from hospital tap water in Japan and their chlorine resistance. Biocontrol Sci 2007;12:39-46.

Giao MS, Wilks S, Azevedo NF, Vieira MJ, Keevil CW. Incorporation of natural uncultivable Legionella pneumophila into potable water biofilms provides a protective niche against chlorination stress. Biofouling 2009;25:345-51.

Hong PY, Hwang CC, Ling FQ Andersen GL, LeChevallier MW, Liu WT. Pyrosequencing analysis of bacterial biofilm communities in water meters of a drinking water distribution system. Appl Environ Microbiol 2010;76:5631-5.

Hunt AP, Parry JD. The effect of substratum roughness and river flow rate on the development of a freshwater biofilm community. Biofouling 1998;12:287-303.

Jones RT, Robeson MS, Lauber CL, Hamady M, Knight R, Fierer N. A comprehensive survey of soil acidobacterial diversity using pyrosequencing and clone library analyses. Isme J 2009;3:442-53.

Keinanen-Toivola MM, Revetta RP, Santo Domingo JW. Identification of active bacterial communities in a model drinking water biofilm system using 16S rRNA-based clone libraries. FEMS Microbiol Lett 2006;257:182-8.

Kormas KA, Neofitou C, Pachiadaki M, Koufostathi E. Changes of the bacterial assemblages throughout an urban drinking water distribution system. Environ Monit Assess 2010;165:27-38.

Kuiper M. Occurrence of Legionella pneumophila and Hartmannella vermiformis in fresh water environments and their interactions in biofilms. Wageningen Universiteit 2006.

Kuiper MW, Wullings BA, Akkermans ADL, Beumer RR, van der Kooij D. Intracellular proliferation of Legionella pneumophila in Hartmannella vermiformis in aquatic biofilms grown on plasticized polyvinyl chloride. Appl Environ Microbiol 2004;70: 6826-33.

Kuiper MW, Valster RM, Wullings BA, Boonstra H, Smidt H, van der Kooij D. Quantitative detection of the free-living amoeba Hartmannella vermiformis in surface water by using real-time PCR. Appl Environ Microbiol 2006;72:5750-6. 
Lane DJ. 16S/23S rRNA sequencing. In: Stackebrandt E, Goodfellow M, editors. Nucleic acid techniques in bacterial systematics. New York: John Wiley \& Sons; 1991. p. 115-75.

LeChevallier MW, Schulz W, Lee RG. Bacterial nutrients in drinking water. Appl Environ Microbiol 1991;57:857-62.

Lee Dong-Geun, Park SJ, Kim SJ. Influence of pipe materials and VBNC cells on culturable bacteria in a chlorinated drinking water model system. J Microbiol Biotechnol 2007;17: 1558-62.

Li D, Li Z, Yu JW, Cao N, Liu RY, Yang M. Characterization of bacterial community structure in a drinking water distribution system during an occurrence of red water. Appl Environ Microbiol 2010;76:7171-80.

Lipponen MTT, Martikainen PJ, Vasara RE, Servomaa K, Zacheus O, Kontro MH. Occurrence of nitrifiers and diversity of ammonia-oxidizing bacteria in developing drinking water biofilms. Water Res 2004;38:4424-34.

Liu $R$, Yu Z, Zhang $H$, Yang M, Shi B, Liu X. Diversity of bacteria and mycobacteria in biofilms of two urban drinking water distribution systems. Can J Microbiol 2012;58: 261-70.

Manz W, Kalmbach S, Bendinger B, Szewzyk U. In situ probing reveals Aquabacterium commune as a widespread and highly abundant bacterial species in drinking water biofilms. Water Res 2000;34:575-81.

Martiny AC, Jorgensen TM, Albrechtsen HJ, Arvin E, Molin S. Long-term succession of structure and diversity of a biofilm formed in a model drinking water distribution system. Appl Environ Microbiol 2003;69:6899-907.

Martiny AC, Albrechtsen HJ, Arvin E, Molin S. Identification of bacteria in biofilm and bulk water samples from a nonchlorinated model drinking water distribution system: detection of a large nitrite-oxidizing population associated with Nitrospira spp. Appl Environ Microbiol 2005;71:8611-7.

Messi P, Anacarso I, Bargellini A, Bondi M, Marchesi I, de Niederhausern S, et al. Ecological behaviour of three serogroups of Legionella pneumophila within a mode plumbing system. Biofouling 2011;27:165-72.

Nam YD, Jung MJ, Roh SW, Kim MS, Bae JW. Comparative analysis of Korean human gut microbiota by barcoded pyrosequencing. PLoS One 2011;6.

Niquette P, Servais P, Savoir R. Bacterial dynamics in the drinking water distribution system of Brussels. Water Res 2001;35:675-82.

Pedersen K. Biofilm development on stainless-steel and PVC surfaces in drinking-water Water Res 1990;24:239-43.

Percival SL, Walker JT. Potable water and biofilms: a review of the public health implications. Biofouling 1999;14:99-115.

Pruesse E, Quast C, Knittel K, Fuchs BM, Ludwig WG, Peplies J, et al. SILVA: a comprehensive online resource for quality checked and aligned ribosomal RNA sequence data compatible with ARB. Nucleic Acids Res 2007;35:7188-96.

Raskin L, Stromley JM, Rittmann BE, Stahl DA. Group-specific 16S rRNA hybridization probes to describe natural communities of methanogens. Appl Environ Microbiol 1994;60:1232-40.

Regan JM, Harrington GW, Noguera DR. Ammonia- and nitrite-oxidizing bacterial communities in a pilot-scale chloraminated drinking water distribution system. Appl Environ Microbiol 2002;68:73-81.
Regan JM, Harrington GW, Baribeau H, De Leon R, Noguera DR. Diversity of nitrifying bacteria in full-scale chloraminated distribution systems. Water Res 2003;37:197-205.

Revetta RP, Pemberton A, Lamendella R, Iker B, Domingo JWS. Identification of bacterial populations in drinking water using $16 \mathrm{~S}$ rRNA-based sequence analyses. Water Res 2010:44:1353-60.

Rickard AH, Leach SA, Buswell CM, High NJ, Handley PS. Coaggregation between aquatic bacteria is mediated by specific-growth-phase-dependent lectin-saccharide interactions. Appl Environ Microbiol 2000;66:431-4.

Rickard AH, McBain AJ, Stead AT, Gilbert P. Shear rate moderates community diversity in freshwater biofilms. Appl Environ Microbiol 2004;70:7426-35.

Roh SW, Kim KH, Nam YD, Chang HW, Park EJ, Bae JW. Investigation of archaeal and bacterial diversity in fermented seafood using barcoded pyrosequencing. Isme J 2010;4:1-16.

Schloss PD, Westcott SL, Ryabin T, Hall JR, Hartmann M, Hollister EB, et al. Introducing mothur: open-source, platform-independent, community-supported software for describing and comparing microbial communities. Appl Environ Microbiol 2009;75: 7537-41.

Schmeisser C, Stockigt C, Raasch C, Wingender J, Timmis KN, Wenderoth DF, et al. Metagenome survey of biofilms in drinking-water networks. Appl Environ Microbiol 2003;69:7298-309.

Simoes LC, Simoes M, Vieira MJ. Intergeneric coaggregation among drinking water bacteria: evidence of a role for Acinetobacter calcoaceticus as a bridging bacterium. Appl Environ Microbiol 2008;74:1259-63.

Stahl DA, Amann RI. Development and application of nucleic acids probes. In: Stackebrandt E, Goodfellow M, editors. Nucleic acid techniques in bacterial systematics. New York: John Wiley \& Sons; 1991. p. 205-48.

Vaerewijck MJM, Huys G, Palomino JC, Swings J, Portaels F. Mycobacteria in drinking water distribution systems: ecology and significance for human health. FEMS Microbiol Rev 2005;29:911-34.

Valster RM, Wullings BA, Bakker G, Smidt H, van der Kooij D. Free-living protozoa in two unchlorinated drinking water supplies, identified by phylogenic analysis of 18S rRNA gene sequences. Appl Environ Microbiol 2009;75:4736-46.

Valster RM, Wullings BA, van den Berg R, van der Kooij D. Relationships between free-living protozoa, cultivable Legionella spp., and water quality characteristics in three drinking water supplies in the Caribbean. Appl Environ Microbiol 2011;77: 7321-8.

Weisburg WG, Barns SM, Pelletier DA, Lane DJ. 16S ribosomal DNA amplification for phylogenetic study. J Bacteriol 1991;173:697-703.

White DC, Sutton SD, Ringelberg DB. The genus Sphingomonas: physiology and ecology. Curr Opin Biotechnol 1996;7:301-6.

WHO-World Health Organization. Guidelines for drinking-water quality; 2008 [Geneva 27 CH-1211 Switzerland].

Williams MM, Domingo JWS, Meckes MC, Kelty CA, Rochon HS. Phylogenetic diversity of drinking water bacteria in a distribution system simulator. J Appl Microbiol 2004;96:954-64.

Ye L, Zhang T. Pathogenic bacteria in sewage treatment plants as revealed by 454 pyrosequencing. Environ Sci Technol 2011;45:7173-9. 